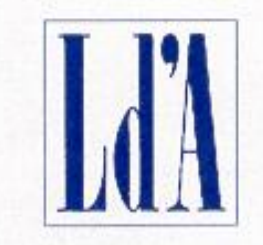

CENTRO STUDI LUCA D'AGLIANO

WWW.DAGLIANO.UNIMI.IT

CENTRO STUDI LUCA D'AGLIANO

DEVELOPMENT STUDIES WORKING PAPERS

N. 352

April 2013

Multinationals and Industrial Policy

Giorgio Barba Navaretti*

Anthony J. Venables**

* University of Milan and Centro Studi Luca d'Agliano ** University of Oxford and CEPR 


\title{
Multinationals and Industrial Policy
}

\author{
Giorgio Barba Navaretti, \\ University of Milan and Centro Studi Luca d'Agliano \\ Anthony J. Venables \\ University of Oxford and CEPR
}

\begin{abstract}
Are there benefits to the host country from multinational investments? Does potential value from these investments make active industrial policy worthwhile? We answer the first question affirmatively, having reviewed economic principles and evidence concerning the effects of projects locating in (or not being off-shored from) a country. On the second, policy can have a limited effect in influencing location decisions, but it is doubtful that it is cost effective. Implementation faces lack of information, risk of capture and, in many cases, nonrigorous processes. Competition between jurisdictions means that much policy is investment diversion not investment creation. There is a case for supra-national controls (as with EU State Aid regulations), for policy to be used only for well-defined market failures, and for better implementation and more rigorous ex-ante appraisal and ex-post evaluation.
\end{abstract}

Keywords: Multinational Corporations, Industrial Policy

\section{JEL classification:}

Authors' Addresses:

G. Barba Navaretti

Department of Economics

University of Milan

Via Conservatorio 7

20121 Milano, Italy

barba@unimi.it

\author{
A.J. Venables \\ Department of Economics \\ University of Oxford \\ Manor Road \\ Oxford OX1 3UQ UK \\ tony.venables@economics.ox.ac.uk
}

* Thanks to Massimo Florio, Beata Javorcik, Gianmarco Ottaviano, Henry Overman, David Vines and an anonymous referee for suggestions and comments and to Silvia Cerisola and Veronica Lupi for background research and data processing. 


\section{Introduction}

The ability to attract and retain investments by internationally mobile firms is often seen as a condition for economic success. Modest size investments - creating a few thousand jobs in an economy employing tens of millions of people - are sometimes viewed as a cause for celebration. Policy makers, particularly in mature economies, have been vocal on the need to attract new investors and stem the off-shoring of activities, and have argued for re-shoring of previously off-shored operations. The following quote from President Obama summarises these views:

"Today, I'm calling for all of us to come together - private sector industry, universities, and the government - to spark a renaissance in American manufacturing and help our manufacturers develop the cutting-edge tools they need to compete with anyone in the world... With these key investments, we can ensure that the United States remains a nation that 'invents it here and manufactures it here' and creates high-quality, good paying jobs for American workers." President Obama, June 24, 2011.

What is the value of such investments to the host economy? And is there a case for using industrial policy to attract internationally mobile firms and investment projects?

Countries benefit from having a sizable tradable goods (and/or services) sector, and one that is relatively stable with a 'deep comparative advantage' generated by a sequence of long-term investment decisions that have built up human and physical capital. This economic base comes partly from growing domestic firms, support for which has been used to justify industrial policy. The classic infant industry argument is that firms (or perhaps sectors) initially have relatively low technical capacity and face obstacles in obtaining the complementary inputs needed to raise capacity. Industrial policy may be needed to support firms' development through this - hopefully temporary - period.

The economic base is also provided by mature firms, many of them multinationals (MNCs), some locally based and some foreign owned. ${ }^{2}$ These firms are the subject of this paper, and the policy arguments applicable to them are quite different. They generally have a high level of technical capacity and good access to finance; the infant industry argument is not applicable as MNCs do not need support to attain their own production possibility frontier. There are two alternative arguments for industrial policy towards such firms. One we refer to as location, deriving from possible benefits of having an MNC locate a project in our country rather than elsewhere. The purest case is a project that will be undertaken in one of several alternative locations; what is the value of it coming to us rather than going elsewhere? The other is ownership; what are the effects of changing ownership of existing activities, and should policy seek to influence the ownership (or control) of activity in a country? ${ }^{3}$

If the case can be made that there are advantages from MNC activity, then the issue becomes: what is the effectiveness (and cost effectiveness) of policy measures to influence these locational and ownership decisions? There is wide acceptance of the need for structural

\footnotetext{
1 Our focus will be on investments in high-income countries; the developing country literature has been recently surveyed by Harrison and Rodriguez-Clare (2010).

${ }^{2}$ Much of the literature has focused on the effects of foreign direct investment (FDI), in particular inwards investment by foreign firms. We use a wider concept, using the term MNC to refer to firms - both national and foreign - facing international location choices.

${ }^{3}$ The theory literature makes the distinction between horizontal and vertical FDI. The latter is footloose, moving in response to cost differences, while the former locates to serve local markets. Horizontal is therefore more likely to involve displacement, although 'local' might mean an entire region - eg the EU - rather than a particular country (see Barba Navaretti and Venables, 2004).
} 
reforms to improve the business environment, and this can legitimately extend to dialogue with firms to understand their needs for complementary public investments in physical, human, or institutional capital. However, more directly interventionist measures suffer from two sorts of problems, one national and the other international. At the national level imperfect information makes it hard to implement policy. The intention is to support projects which would not have gone ahead in the absence of support, but which are nevertheless viable and sustainable in the long run. Identifying such projects is difficult. On the one hand there may be 'deadweight loss' if policy supports investments that would have been made in any case. On the other, policy may support projects which stand little chance of becoming commercially viable. Lobbying by firms may worsen rather than improve these informational problems, as well as creating risk of capture by vested interests. At the international level, the problem is that of competing jurisdictions bidding for scarce investments and leading to a prisoners' dilemma in which subsidies divert investment between locations, while creating little additional investment. This makes it imperative that policy measures are placed within a rigorous international regime.

The bulk of the paper deals with arguments surrounding the location of MNC activity. These arguments apply to both green-field investments and other MNC decisions that affect location. Thus, if investment in or acquisition of an existing plant prevents it from closure or moving 'off-shore', this constitutes a location decision. In the following section we explore the effects of such location decisions. While the simplest economic analysis suggests these effects are of zero value - an MNC investment simply displaces some other activity of equal value - we argue that positive net effects occur both through the labour market and various non-market spillovers.

Sections 3 and 4 turn to policy, reviewing existing policy practise and the evidence on policy effectiveness. These sections cover both general measures (working on the business environment and affecting all firms) and selective ones (targeting particular activities). The broad conclusion is that these measures do affect location decisions, although their effectiveness is generally higher in regions with deep comparative advantage and where agglomeration forces are present. In these areas general measures and measures addressing specific market failures (R\&D) investments have had effect in retaining and attracting potentially mobile investments. In more backward areas subsidies and targeted selective measures have sometimes been successful in capturing new investments.

However, the case for spending public funds needs to pass a high hurdle of costeffectiveness, bringing substantial real income gains and delivering value for money. From the point of view of a wide region (such as the EU) it is important that there is investment creation not just investment diversion. These are tough criteria, and we think that most industrial policy fails to satisfy them. In our view, the chances of success might be increased if three principles are followed. First, there needs to be a rigorous framework of supranational rules to prevent wasteful competition for projects. Second, policy should operate on clearly identified market failures. Third, effective procedures need to be put in place at the point where decisions are taken.

Section 5 addresses the question of ownership of a given set of investments. There is some evidence of beneficial effects from foreign acquisition of domestic assets but, particularly for developed countries, the evidence is weak and hamstrung by selection problems. We take concerns that MNCs are less embedded in the economy seriously, although suspect that it varies greatly by firm, sector, and country of origin. Excessive 'short-termism' is probably not a phenomenon particular to the activities of MNCs. 


\section{The location of activity}

What is the value of an MNC project to a host economy? Answering this question is complex because a project will have both direct effects and indirect effects as it interacts with and possibly displaces other activities. There are three main channels through which these effects may be felt. One is the product market, the second the labour market, and the third is through spillovers or externalities from the project.

We consider first projects that produce output which is highly tradable internationally. The example we have in mind is a production facility such as a car assembly. Such plants typically supply an international market and the investment will go ahead somewhere, the question being where. The location decision therefore has no final product market implications, and the project's main impacts on the host country will be through the labour market and any spillover effects that it may bring.

While this case is important, and perhaps the most prominent in public debate, we note that it is only a fraction of MNC investment activity. Looking just at inwards investments by foreign MNCs in the EU in 2007, $71 \%$ by value is M\&A activity, rather than green-field investment (the proportion being much higher for the UK, France, Germany and Italy, and lower for transition countries). Furthermore, a high proportion of FDI is in non-tradable activity such as retailing and services. For a given size of the domestic market, these investments have strong product market displacement effects; they are equivalent to ownership changes, and we discuss them in section 4. Internationally tradable activities, such as manufacturing, HQ activities, and business services account for approximately half of green-field flows, but they vary widely across countries. In core economies and in the UK headquarter and business services are relatively large recipients of FDI, while manufacturing accounts for a larger share in Central and Eastern European economies.

\section{MNCs, employment, and wages}

The primary effect of a MNC project in a tradable sector is the employment of workers. In the standard textbook case these workers are paid at the going wage and move from other jobs in the economy. This applies both to jobs directly created in the project, and those in ancillary upstream (supplier) or downstream (customer) activities. The net contribution of this employment to the economy is the wage (inclusive of tax payments), minus the output foregone elsewhere in the economy; this is equal to the value marginal product of labour, in turn equal to the wage. ${ }^{4}$ Thus, a small MNC investment is of no value to the economy.

While this is the standard analysis it is misleading when it comes to evaluating the effects of a substantial (non-marginal) MNC presence. Such a presence is like to bid up wages, although whether or not this is a real income gain depends on who pays the higher wages. To see the arguments, Figure 1 has the economy's total labour force on the horizontal axis, and the right hand fraction gives employment in non-tradables which, for present purposes, we take as fixed. The downwards sloping curve from the left hand axis is the demand curve for labour in the domestic non-MNC tradables sector (labeled domestic traded). This is the value marginal product of labour schedule, labeled $p F^{\prime}\left(L_{D}\right)$, and firms in this sector can be thought of as home based firms with relatively immobile plants. Internationally mobile employment in MNCs is the middle section, and we use the diagram to establish the effects of expanding this employment. Given the level of MNC employment indicated, the wage is

\footnotetext{
4 We suppose that the level of profits is not significantly affected by location choice, and shareholdings are in any case internationally dispersed.
} 
w', and we compare this with a hypothetical initial situation with no MNC employment and wage $w_{0}$. Comparing situations, the presence of MNCs clearly raises the wage in the economy, and the magnitude of this depends on the slope of the labour demand curve, $p F^{\prime}\left(L_{D}\right)$. We discuss the determinants on this slope below but first ask, what is the value to real income of this increase in the wage, i.e. increase in the wage bill of areas $D+B+G+C$ ?

\section{Figure 1: Gains from inwards investment}

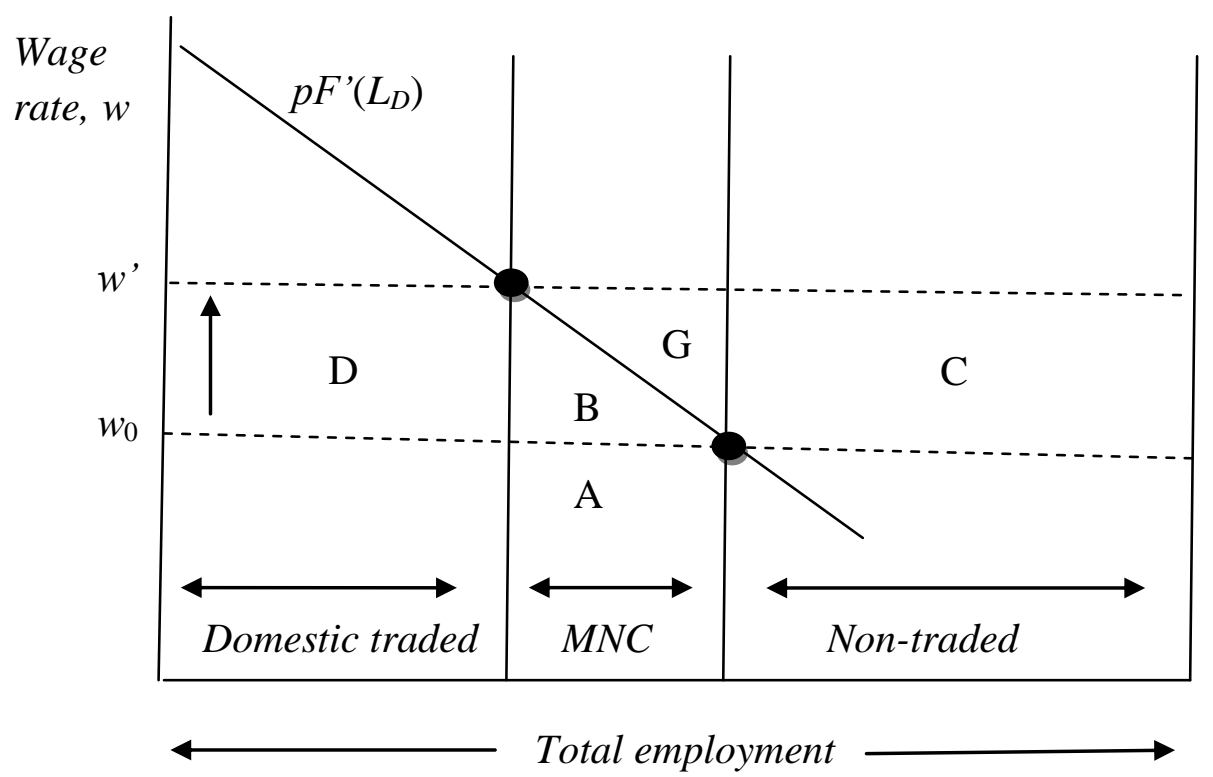

Area $\mathrm{C}$ is an increase in wages in the non-traded sector which, since the prices of non-traded goods are set in the domestic economy, is passed on as higher prices for domestic consumers. Area $\mathrm{C}$ is therefore a transfer payment not a real income gain, because of this price and costof-living effect.

Area D is a transfer payment to workers in non-MNC traded employment at the expense of other recipients of income in this sector (profits and rents); as such it is not a source of aggregate income gain.

The action comes entirely within the area of MNC jobs. These displace domestic (nonMNC) traded output of $A+B$, and pay wages $A+B+G$, so the net gain to the economy is G. The underlying mechanism here is the following. Labour demand from MNCs bids up wages in the economy. Non-traded sectors pass on the wage increase (area C) and some domestic tradable sector firms absorb the wage increase (area D). Other domestic tradable sector firms exit, reducing output by area $\mathrm{A}+\mathrm{B}$. However, incumbent MNCs can, at least in the example shown, absorb the higher wages. Since the contribution of these firms to the economy is simply the wage bill, this increase in wage payments is a net benefit (not a transfer payment within the domestic economy). It is essentially a terms of trade improvement, as MNCs are now paying more for the services (labour) that they purchase in the domestic economy.

While this analytical framework is very simple it contains several important messages. First, 
there is a source of real income gain if employment in MNCs, able to bear higher wage costs, replaces non-MNC jobs which are sufficiently low value that they cannot bear the higher wage costs. ${ }^{5}$ Second, the real income gains are proportional to MNC employment squared. More precisely, area $\mathrm{G}=p F^{\prime \prime} M^{2} / 2$ where $M$ is MNC employment, and $p F$ ', is the slope of the non-MNC labour demand curve, so $M p F^{\prime \prime}$ is the size of the wage increase. Of course, this means that a small MNC investment viewed in isolation delivers zero real income gain, which is precisely the argument suggested by marginal analysis.

The key parameter in this argument is the downwards slope of the non-MNC labour demand curve (or, in a more general framework, the slope of this relative to a corresponding curve for MNCs). The downwards slope of the curve is due to diminishing marginal returns to labour in non-MNC tradables, and there are three reasons for these diminishing returns.

The first arises if the sector uses, in addition to labour, a fixed factor such as land. ${ }^{6}$ Shrinking employment in the sector then raises land-labour ratios making labour more productive. This is undoubtedly important for many developing and emerging economies, where MNC demand for workers has drawn labour out of agriculture and raised wages as part of the process of structural transformation. It is a less important mechanism for high income countries, although fixed supply of other factors - skills such as entrepreneurship - might have a similar effect.

The second mechanism is a price effect. If the range of traded goods produced by non-MNCs in the economy is sufficiently differentiated from products produced by other countries then their price is endogenous: contracting supply will raise the price, giving the marginal value product schedule a downwards slope.

Third, and perhaps most importantly, there is a wide dispersion in the productivity of domestic firms. The slope of the curve then comes from ordering firms by productivity so that, as the sector contracts, the least efficient firms exit. There is now a considerable amount of research pointing to the wide variation of productivity levels across firm in the economy, and to the fact that internationally active and multinational firms generally have higher productivity (Bernard et al. 2012, Yeaple 2009).

The essential point is then that high productivity MNCs replace low productivity domestic firms; some of the gains from this productivity accrues to international owners of these firms but, as wages get bid up (by further MNC entry), more of it gets transferred to domestic workers. ${ }^{7}$ General equilibrium effects of this type are hard to quantify, but have surely been important in countries such as Ireland, and are probably the main source of benefit in countries with a substantial MNC presence. $^{8}$

\section{MNCs and clusters}

The second source of real income gain from MNCs comes from complementarities between MNCs and local firms, arising either through market linkages or non-market externalities.

\footnotetext{
5 This corresponds - loosely - to the popular notion that MNCs create 'good jobs'.

6 And this factor is not intensively used by MNCs.

${ }^{7}$ It is possible that rising wages causes MNCs to exit (as with reshoring of some activities from China), but the rising share of MNC employment indicates that this displacement effect is small

${ }^{8}$ This simplified framework does not take into account distortions in local labour markets. The cost-benefit literature has shown that in very distorted framework it would be appropriate to use shadow wages and prices (see Del Bo et al., 2011)
} 
MNC investments create demand for intermediate inputs and possibly also new sources of supply of intermediate goods. There is then an incentive for suppliers/ customers to co-locate with the MNC operation as firms benefit from proximity within a cluster. For example, Baldwin and Venables (2013) show how the movement of a plant that is strongly linked to other stages of the production process (such as an assembly plant) can trigger relocation of a wide range of other activities (component suppliers). This in turn can affect further relocation decisions of assemblers and so become a cumulative process. Clusters are likely to be subject to threshold effects, implying that key investments can promote further entry and have a multiplier effect. Conversely, failure to attract or to retain investments can lead to weakening and potential unraveling of a cluster.

What are the implications of this for the value of MNC investments? First, these linkages amplify the effects described in the preceding subsection; in addition to the jobs created directly by the MNC investment further new jobs may be created in the cluster. And just as there are cumulative causation benefits from growing a cluster, so there is also the possibility of a vicious circle of decline. Relocation or closure of a key firm may trigger the unraveling of a cluster that is then hard to regain. Policy makers in mature economies are troubled by the off-shoring of local operations and the relocation of pre-existing MNC plants, as they are concerned at the threat that this poses to existing industrial clusters.

Additional gains accrue if the cluster has the effect of increasing the efficiency of firms, and there are several well researched mechanisms through which this occurs. Communication and inter-firm trade is facilitated, there is a greater availability of specialized products and workers, and there is also likely to be intense competition between firms. Skill development is facilitated as workers churn between firms transferring skills and knowledge (Nathan and Overman, 2013). These factors are of direct benefit as they raise productivity; they also imply that jobs within a cluster are likely to be relatively robust to rising wages.

While these arguments apply to the location decisions of internationally mobile plants, domestic and foreign owned, there is evidence that foreign MNCs can play a particularly crucial role. An important mechanism is that MNC entry can lead to upgrading of the quality and productivity of suppliers. A number of studies find this effect, including work in transition economies (Javorcik 2004, Javorcik and Spatareanu (2008) and developing countries (Blalock and Gertler 2008, Liu 2008, and Du, Harrison and Jefferson 2011). Noteworthy is Chung, Mitchell and Yeung (2003) which explicitly identifies MNCs in the American automotive component industry in the 1980s. They find that Japanese FDI into automotive assembly was associated with overall productivity improvements in the US auto component industry. The effects are also important in non- manufacturing sectors; Javorcik, Keller and Tybout (2008) finds that the entry of Wal-Mart into Mexico facilitated the modernization of the retail sector and stimulated fundamental changes in the relationship between retailers and suppliers.

\section{Productivity spillovers and $R \& D$}

Investments generate further real income gains if they create positive externalities, for example raising productivity in other firms. There is a substantial empirical literature investigating these effects, and the mechanisms through which they operate.

While most of the literature has looked at inwards investments by foreign MNCs, we are interested in the wider context of plant location. A nice study of this is Greenstone et al.

\footnotetext{
${ }^{9}$ For additional studies see the literature review by Greenaway and Gorg (2004) and Smeets (2008).
} 
(2010) who look at the effect of the opening of a large manufacturing plant in a US county. They find, comparing counties that win such plants with those that don't, total factor productivity in incumbent plants in winning counties is, after five years, a full 12 percent higher than it is in equivalent plants in losing counties. The effect is larger for plants that share similar labour and technology pools with the new plant. While the study is not about MNCs per se, it demonstrates the powerful impact of capturing a new major plant.

Much of the literature looks at the effect of investments by foreign MNCs, and this too finds evidence of positive spillovers to incumbent firms. For example, Haskel, Pereira and Slaughter (2007) use a panel of UK manufacturing plants from 1973 through 1992 and find that a 10 percentage-point increase in foreign presence in a UK industry raised the total factor productivity of that industry's domestic plants by about 0.5 percent. They also show that spillover effects were larger for initially worse performing plants. ${ }^{10}$

A number of studies have attempted to identify the mechanisms through which such spillovers occur. Foreign affiliates operating in Britain are responsible for a large share of R\&D undertaken in the UK (Griffith, Redding and Simpson 2004), suggesting that foreign affiliates in Britain may be a source of knowledge spillovers. Movement of labour is an important mechanism and has been analysed in several studies. Balsvik (2011) documents extensive labour flows from MNCs to non-MNCs in Norwegian manufacturing and finds significant and quantitatively important positive correlation between the share of workers with MNC experience and the productivity of the non-MNCs. Workers with multinational experience contribute 20 percent more to the productivity of their plant than workers without such experience, even after controlling for differences in unobservable worker characteristics.

There is also some evidence that MNCs offer more opportunities for training and professional development than local firms, particularly in developing and transition economies. For example, Filer et al. (1995) find that foreign-owned firms in the Czech Republic spend considerably more than domestic firms on training. The mechanism may be less important in high-income economies, although arrival of Japanese firms in Europe and North America in the 1980s has been reported to have been associated with higher levels of training.

\section{Regional employment and unemployment:}

A further source of gain arises if labour used by the MNC would otherwise have been unemployed. The wide and persistent differences in unemployment and participation rates across European regions reflects the unattractiveness of some regions for investment, so MNC investment in such regions is particularly valuable.

In assessing the potential contribution of MNCs to employment in these regions, several points need to be made. First, the local employment impact goes well beyond direct employment on the project. Moretti (2010) shows that an exogenous increase in employment in a tradable industry in a US city has significant effects through 'local multipliers'. Thus, for each additional job in manufacturing in a city, 1.59 further jobs are created in the nontradable sector in the same city. This number varies across the manufacturing sector in which the job is created, rising to 4.9 for high-tech sectors. It is also higher if the exogenous shock takes the form of skilled employment creation (2.52 additional jobs versus 1.04 for unskilled). These employment effects are concentrated in the non-tradable sector, and there is no significant effect on employment in other tradable sectors. Further work by Moretti and

10 See also Gorg and Strobl (2001), Gorg and Greenaway (2004), Smeets (2008) for reviews of this literature. 
Thulin (2012) compares the US and Sweden, finding that effects are present but somewhat smaller in Sweden.

However, even though new member states and Ireland have been successful in attracting new FDI, in core EU economies there is little evidence that MNC activity is particularly concentrated in high unemployment regions. On the contrary, inwards FDI in these countries is disproportionately concentrated in few high income regions. Looking just at green-field investments between 2003 and 2007, only a small share went to regions eligible for Regional Aid under EU regulations on State Aid: 9\% in Germany, 8\% in Italy and 3\% in the UK.. It is likely that this is the effect of agglomeration and clustering factors that, as we will see in the policy section below, are generally crucial factors in attracting foreign firms.

\section{Product market displacement}

In this section we have focused on tradable activities, and on the labour market and spillover effects they create. For projects producing non-tradables the displacement story is likely to be quite different, and much more direct. If the size of the domestic market for the product is given then a new supplier will inevitably crowd-out an existing one. Even a new investment is then, essentially, just equivalent to an ownership change. It is like M\&A activity, as the ownership of capacity in the industry has changed with little net effect on the sector's overall level of activity. We therefore postpone discussion of this until section 5.

\section{Policy}

The preceding section suggests that there are substantial benefits from having internationally mobile projects (particularly in tradable sectors) locate in the domestic economy. While this is a necessary condition for using policy, it is obviously not sufficient. This section reviews policy instruments and EU practice, and then turns to assessing the effectiveness of policy, a difficult task because of the problem of identifying the counterfactual.

Policy instruments can operate in different ways. One way is general, working on the business environment as it affects all firms. Another is selective, targeting particular activities. Both types of policy suffer, to varying degrees, from two fundamental problems.

One is that of jurisdictions competing against each other and generating a prisoners' dilemma; investment is diverted from other locations, but little new investment may be created. If all countries use policy there may be little net effect on outcomes but considerable transfer of resources to firms. This is the motivation for restricting the use of policy by supranational regulations, such as the EU State Aid rules.

The other problem, particularly for selective policies, is to do with the informational requirements of implementing policy. The policy maker is faced with a large set of projects, each with its own private and social value. The objective is to support those for which the social value is positive and the private value negative (so that support is both socially valuable and necessary for the project to proceed). Both these numbers need to be known (not just the difference between them which is the value of the market failure) in order to avoid supporting projects with negative social value or which would be done in any case ('deadweight loss'). In practice, neither number is known with any degree of precision. The response is either to go for a rule-based approach, so that all projects meeting certain criteria (e.g. location in disadvantaged regions) are supported. Or alternatively, a discretion-based approach, using such information as can be obtained, combined with judgment, and 
negotiation. The former approach will obviously make a lot of errors of both types; the latter is vulnerable to manipulation and corruption.

\section{General Instruments}

The aim of general policies is to reduce the cost of operating for all sectors and firms. Some of these policies are uncontroversial, such as providing good physical infrastructure and a stable regulatory and institutional environment. Generally dubbed as structural reforms, they are at the heart of many EU policy prescriptions. They are measured and monitored by competitiveness indicators such as the time to complete bureaucratic procedures, these indicators providing accessible and comparable measures of the attractiveness of individual countries to the location of business. ${ }^{11}$

Interestingly, the performance of individual countries within the EU varies widely with respect to these competitiveness indicators, as shown in table 1 below. One would expect the competitive behavior of countries, the pressure of the European Commission and the availability of comparable indicators to lead to convergence. However, significant differences remain, partly because of national preferences on institutional arrangements and design, and partly because of the defense of special interests and rents.

\section{TABLE 1: EASE OF DOING BUSINESS, SELECTED EU COUNTRIES}

\begin{tabular}{|llllllll|}
\hline & $\begin{array}{l}\text { Time to Start } \\
\text { a Business } \\
\text { (days) }\end{array}$ & $\begin{array}{l}\text { Time to Deal } \\
\text { with } \\
\text { Construction } \\
\text { Permits (days) }\end{array}$ & $\begin{array}{l}\text { Time to Get } \\
\text { Electricity } \\
\text { (days) }\end{array}$ & $\begin{array}{l}\text { Time to } \\
\text { Register a } \\
\text { Property } \\
\text { (days) }\end{array}$ & $\begin{array}{l}\text { Time to } \\
\text { Export } \\
\text { (days) }\end{array}$ & $\begin{array}{l}\text { Time to } \\
\text { Enforce } \\
\text { Contracts } \\
\text { (days) }\end{array}$ & $\begin{array}{l}\text { Time to } \\
\text { Resolve } \\
\text { Insolvency } \\
\text { (years) }\end{array}$ \\
\hline France & 7 & 184 & 79 & 59 & 9 & 390 & 1.9 \\
Germany & 15 & 57 & 17 & 40 & 7 & 394 & 1.2 \\
Italy & 6 & 284 & 155 & 24 & 19 & 1210 & 1.8 \\
Spain & 28 & 182 & 101 & 13 & 9 & 510 & 1.5 \\
UK & 13 & 99 & 105 & 29 & 7 & 399 & 1.0 \\
\hline
\end{tabular}

Source: WB Doing Business 2013

General measures also include corporate taxation policies (tax rates and treatment of investment, depreciation, and $R \& D$ ), and there is considerable evidence that taxation policy has been effective in attracting foreign capital (Devereux 2008, Devereux and Lockwood 2006, Benassy-Quéré et al. 2007). Surveys of these empirical studies conclude that corporate taxation significantly affects FDI flows (Hines, 1999, Devereux and Griffith, 2002, De Moij and Ederveen, 2003).

Whereas the marginal investment decision (the intensive margin) and therefore the size of the investment is affected by the Effective Marginal Tax Rate (EMTR), what matters for the discrete location of new plants is the Effective Average Tax Rate (EATR, a weighted average of the EMTR and statutory corporate tax rates). De Mooij and Ederveen (2008) carry out a meta-analysis of different studies to estimate the effects of corporate tax on different margins. They suggest that a reduction of 1 percent in the EATR increases foreign investment flows by

\footnotetext{
${ }^{11}$ The main and best established sources of these indicators are the World Bank "Doing Business Reports" and the World Economic Forum "Global Competitiveness Indicators". See also European Commission (2012) "Industrial performance Scoreboard and member Sates' Competitiveness Performance and Policies", SWD(2012)298.
} 
5.9 percent. If count data on the number of location of FDI are used in order to isolate the impact on new investment decisions, the response drops to 3.2 percent.

Establishing that policy might have influenced firms' location decisions does not mean that this has been socially valuable, particularly from the standpoint of a group of countries such as the EU. Devereux, Lockwood and Redoano (2008) look at the patterns in EMTR and statutory tax rates for the OECD countries between 1982 and 1999 and find evidence of strategic competition to attract FDI. Indeed, corporate tax rates have been declining since the early 1980s, and this pattern strengthened in the EU after the accession of the new member states (which had an initial lower rate of corporate taxation than the old members). Figure 2 indicates that there has been a downwards tendency in these rates, which have fallen in every country except Hungary over the period $2000-2012$.

However, while this decline in rates is consistent with jurisdictions competing in a 'race to the bottom' there are still wide difference across European countries, with rates as low as $12.5 \%$ in Ireland and much higher in Italy, France or Germany. These differences arise partly from countries' different fiscal positions, and also perhaps from the fact that the effectiveness of lower taxation is country and context specific. Hansson and Olofsdotter (2010) study how the effectiveness of tax policy in attracting bilateral FDI flows (in the EU 27 countries between 1995 and 2006) depends on the interaction between corporate taxation and agglomeration economies. They show that new member states have used tax policies aggressively and effectively to attract mobile capital. In contrast, old member states have used changes in corporate taxation to a lesser extent, and the authors suggest that this is because they can rely on the benefits of existing agglomerations to attract or retain FDI. These findings are consistent with a theoretical model developed by Konrad and Kovenock (2009) which shows that the equilibrium tax rate is higher in countries with old sunk investments than in countries 'lean and hungry' for new investment flows. Bénassy-Queré, Fontagné and Lahrèche-Révil (2003) show that within imperfect competition models tax competition is consistent with differences in tax rates because trade costs and scale economies determine a home country bias that favours large countries.

The argument is essentially that previous investments (and established agglomerations) generate an immobile tax base. Clusters offer a deeper comparative advantage that enables established centres to attract investment. Lower tax rates do indeed affect the cost of producing in a given country, but their effect could be reversed easily, if it is not rooted in broader factors of attraction. Moreover, the advantage provided by low taxes can easily be replicated elsewhere. Attractiveness based on these factors makes countries highly substitutable as final production locations and subject to tax competition. This suggests a sequencing of stages. A favourable fiscal framework might help in attracting an initial wave of investments which might create a critical mass of activities and give rise to agglomeration factors and a deep comparative advantage. The experience of several emerging economies (Singapore) or non-core European economies (Ireland, Slovakia) follows this path. 


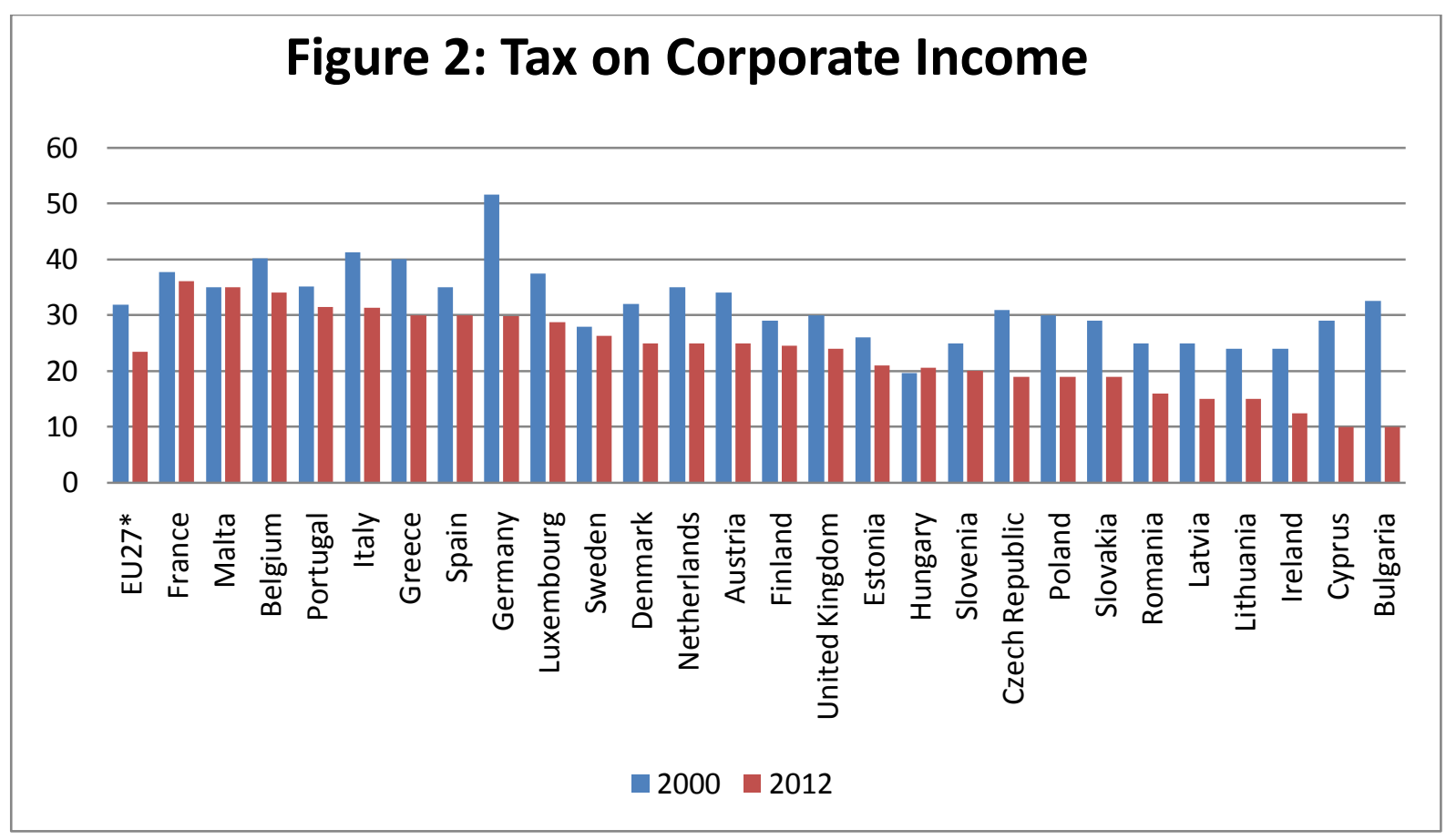

Source: OECD.

\section{Selective instruments}

Selective instruments of industrial policy are classified as State Aid by EU legislation. State Aid is, in principle, incompatible with the common market. The most relevant exemption clauses are those of Article 87(3)(a) and Article 87(3)(c) of the EC Treaty: "aid to promote the economic development of areas where the standard of living is abnormally low or where there is serious unemployment" and "aid to facilitate the development of certain economic activities or certain economic areas, where such aid does not adversely affect trading conditions contrary to the common interest".

Table 2 reports figures for three year averages of State Aid (excluding transport, agriculture and fisheries) between 1997 and 2011 divided by instruments (table 2A) and by country (table 2B). Instruments are divided into horizontal and vertical. Horizontal measures are targeted to firms operating in a disadvantaged region (Regional Aid) or performing particular classes of activity, such as research, development and innovation (R\&D\&I) and climate change and environmental protection. Other horizontal measures include rescue and restructuring of firms in difficulty; aid for small and medium-sized enterprises; employment; training; risk capital; services of general economic interest. Expenditure on horizontal measures has increased in recent decades, driven largely by climate related expenditures. Vertical measures are much smaller, and have been declining. Typically they have taken the form of support for declining sectors such as coal and some manufacturing activities.

In aggregate, resources transferred by national and local governments to firms as eligible state aid are substantial, at around $0.5 \%$ of EU's GDP but have declined in recent years. ${ }^{12}$

${ }^{12}$ Excluding crisis aid to the financial sector. 
Looking across the main member states, we note that Germany and France provide much more state aid relative to GDP than do Italy, the UK or Spain (Table 2B). ${ }^{13}$

Table 2A State Aid, annual average by purpose, mn Euros.

\begin{tabular}{clll}
\hline & $1997-01$ & $2002-06$ & $2007-11$ \\
\hline TOTAL & $\mathbf{6 2 1 0 1}$ & $\mathbf{6 1 0 9 9}$ & $\mathbf{5 7 2 0 6}$ \\
HORIZONTAL & 34624 & 41143 & 48926 \\
$\quad$ Regional & 13766 & 10597 & 13469 \\
$\quad$ R\&D\&I & 4960 & 6153 & 9848 \\
$\quad$ Environment & 4102 & 12306 & 13737 \\
VERTICAL & 27477 & 19955 & 8280 \\
\multicolumn{1}{c}{ Manufacturing } & 6297 & 4383 & 2292 \\
\hline
\end{tabular}

*Data in million Euro at constant 2000 prices. Excluding agriculture, fish, transport.

Table 2B State Aid, annual average share of GDP \%, by country.

\begin{tabular}{llll}
\hline & $1997-01$ & $2002-06$ & $2007-11$ \\
\hline EU Total $(*)$ & 0.58 & 0.54 & 0.46 \\
Germany & 0.88 & 0.84 & 0.58 \\
France & 0.82 & 0.38 & 0.52 \\
Italy & 0.54 & 0.38 & 0.26 \\
UK & 0.16 & 0.20 & 0.24 \\
Spain & 0.82 & 0.54 & 0.38
\end{tabular}

(*) according to EU membership in the period. Source: European Commission

While EU State Aids rules set the policy framework, measures are decided and implemented at the national - or in some cases sub-national - level, and quite different procedures and criteria are used. ${ }^{14}$ For example, policy in France has been administered in a centralized fashion, with only $10 \%$ of funds allocated by regional or local authorities. It has also used vertical instruments heavily, focusing on larger firms in a few key sectors (aerospace, nuclear and defense). In contrast, Germany has a much more decentralized Lander based system, but with the Federal authorities playing a coordinating role. The UK has at times been decentralized (with decisions taken by Regional Development Authorities), but it is highly monitored and coordinated by the central administration. In Italy, particularly in recent years, a large share of subsidies has been allocated by the regions in a rather uncoordinated fashion. Even national schemes are generally implemented through local authorities and other institutions. Furthermore, decision taking for both horizontal and vertical funds is generally discretionary. For example, the UK's Regional Selective Assistance scheme and Regional

13 The high level of German state aids is partly due to reunification.

14 This draws on Bouigues and Sekkart (2011). 
Growth Fund have, within the framework of EU State Aids, set formal criteria and also used judgement about numbers of jobs created or preserved, displacement of other activities, and whether the project would go ahead without public funds (additionality).

\section{Effectiveness of policy}

Assessing the effectiveness of industrial policies is a complex and necessarily imprecise task. We focus now on selective policies, and ask three questions. First, is there any evidence that policy has changed the decisions taken by firms? As we will see below, there are studies indicating that there are effects, although they often seem to be weak and it is hard to generalize from rather few studies to a wider picture. Second, if location decisions have changed, then can anything be said about where firms would have located, absent the policy? There is a risk that policy has moved projects around within a region such as the EU, but brought rather few in from outside. Third, even if policy passes these tests, is there evidence that it has been cost effective, delivering value for money?

\section{The effects of policy}

Several studies on individual European countries essentially conclude that regional subsidies have an impact on the location of firms and on the creation of additional jobs, but that their effect generally depends on other regional factors such as the presence of other firms, and the market potential of the location. A recent study that endeavours to get to the causal effect of selective policy is Criscuolo et al. (2012). They exploit multiple changes in the area-specific eligibility criteria for regional selective assistance in the UK. Using panel data on the population of firms they find that the policy has a positive effect on employment, investment and net entry, although not on productivity. The effect is confined to smaller firms, and it is not simply a substitution of jobs away from plants in nearby ineligible areas. The positive impact on area level manufacturing employment comes mainly by reducing unemployment, and the cost per job is estimated to be as low as $\$ 6,300$. Devereux, Griffith and Simpson (2007) examine how discretionary government grants in the UK influence where domestic and multinational firms locate new plants. They find that the effect of a grant on the location decision is small, although considerably larger when interacted with the number of existing plants in the entrant's industry and with the number of foreign investors. Similarly, Mayer (2004) finds that regional aid granted in France has in general a small effect on firms' location. Doubling the support to a region increases the probability of locating there by just 3 percent; the probability increases considerably once market potential, the location of existing French firms and the location decision of other foreign investors is also taken into account. Kokko and Gustavsson (2004) find that in Sweden the effect of foreign investors on unemployment is lower in provinces qualifying for regional aid than in others. So these studies reach a similar conclusion to those analyzing corporate taxation: the effectiveness of support measures depends on their interaction with other factors of attraction, like agglomeration forces, market size and pre-existing investments.

Industrial policy does not only target regions, but also has other objectives, including R\&D. There is evidence that $R \& D$ support through the tax system and selective measures has a significant positive impact on private $R \& D$ spending (for example Guellec and van Pottelsberghe 2003, Falk 2004). Several studies find a large elasticity of R\&D expenses to changes in their user cost arising from corporate taxes (Bloom et al. 2002, Parisi and Sembenelli, 2003). There is also evidence that higher spending translates into higher output as measured by patents or the number of innovative products introduced (Branstetter and 
Sakakibara 2002 for Japan, Bérubé and Mohnen 2009 for Canada, and Bronzini and Piselli 2013 for Italy).

Despite this evidence for effects of policy on location and $R \& D$, evidence of effects on productivity is much weaker. Buigues and Sekkat (2011) survey the literature and find inconclusive results of policy on total factor productivity. Indeed, there is some evidence that less productive plants receive more subsidies so, to the extent that they expand their employment, measured aggregate productivity may be reduced (Criscuolo et al. 2012).

\section{Investment diversion, investment creation.}

Policies are operated by different jurisdictions, typically countries or regions within countries. There is evidently a danger that the effect of policy is simply to relocate projects around a larger region such as the EU as a whole. If countries compete against each other to attract investments there may be escalating subsidies as countries 'race to the bottom'. Indeed, if investment projects are the scarce factor and countries compete to attract them, then all of the economic surplus will be captured by the owner of the project and the benefits for which policy makers are bidding will be driven down to zero.

There are several mitigating forces suggesting that this limiting case will not be reached. We have seen that there is evidence that a wide range of regional features influence firms' location decisions, including market access and presence of similar firms. FDI concentrates in the largest and most advanced regions probably because agglomeration economies and larger nearby markets favour concentration of activity. This suggests that targeting backward regions is an expensive policy instrument to attract investment. While richer countries may seek to use regional assistance as a targeted instrument for regional unemployment, it is an expensive part of a national growth strategy. The competitive pressure on more central regions may therefore be quite low, as is suggested by the corporate income tax differentials that have been maintained (Figure 2).

To the extent that the policy objective is to attract investments to backwards regions, some investment diversion is welcome. A positive note is struck by the finding of Criscuolo et al. (2012) that job creation in areas receiving regional aid is not simply relocation from nearby ineligible regions, although their findings are compatible with there being policy competition between backwards regions in different countries. We simply do not know whether the positive effects of UK regional policy on jobs and employment is investment diversion from other backward regions further afield. Similarly for other cases, such as Ireland. Ireland epitomizes rapid economic growth on the basis of inwards FDI, but much of this is 'export platform' investment, with largely US MNCs seeking a base inside the EU; as such, policy may have just diverted investment from elsewhere in the EU.

The examples of peripheral countries or regions that have been able to become attractive locations for FDI are cases where policy has successfully exploited some deeper comparative advantage. Ireland managed to attract FDI thanks to targeted but comprehensive policies aimed at building an effective platform of skill intensive manufactures and services. The Irish government combined targeted incentives and a favourable fiscal regime with broader policies aimed at fostering human capital (partly through the return of Irish migrants) and infrastructure. Eastern European countries, instead, could exploit the unique combination of cheap labour, a well-educated labour force and free access to the EU market to become an important base for labour intensive manufacturing. 
This suggests that worries about an untrammeled race to the bottom are exaggerated, but it is nevertheless likely that considerable investment diversion goes on. This makes clear the case for supra-national coordination of policies. EU State Aid rules play an important role in doing this, although one that leaves open many opportunities for inefficient competition. The rules only rule out certain forms of aid, but leave others uncapped.

\section{The cost effectiveness of policy}

The third hurdle that policy needs to cross is that of cost-effectiveness. There are numerous examples of policies that led to the construction of projects with extremely high costs per job, or that simply supported firms for a short period of time prior to their collapse (see Dewatripont and Seabright 2006 ). Buigues and Sekkart (2011) in their thorough assessment of public subsidies to business, report widespread evidence of government failures in managing industrial policies. Much less visible, but probably as important, are the cases of deadweight loss; public funds have gone to support investments that would have been made anyway, so there is no additionality and the support offered is simply a grant to shareholders. Furthermore, recall that simply attracting MNC investment is not sufficient for real income gain. A project may simply displace some other activity of similar value unless one or more of the mechanisms discussed in section 2 is operating. Analogous mechanisms may possibly operate in reverse, if industrial policy supports the continuing operation of low productivity firms and impedes structural change.

Generalisation about the cost-effectiveness of policy is well-nigh impossible because of the vast heterogeneity of experience. However, experience points to the need for rigorous exante assessment of spending and implementation; for regional and international disciplines, as provided by EU State aid rules; and for better ex-post monitoring and evaluation to allow for better learning about the determinants of success and failure. ${ }^{15}$

\section{Ownership:}

The policies discussed above are principally concerned with location, i.e. attracting or retaining investment. A distinct set of issues surround changes in ownership that are not associated with changes in capacity. Most MNC activity takes the form of M\&A, acquiring ownership of existing enterprises but not necessarily associated with any change in capacity in the sector. Furthermore, green-field investments in non-tradable sectors may lead to displacement of incumbent firms implying no net capacity change. Do we care about the nationality of ownership of firms, and about such ownership-switching investments?

\section{Productivity and wages}

One reason to care is that the performance (such as productivity levels) of MNCs may be different from that of the domestic firms they replace. Most of the evidence is based on comparisons of inwards FDI with domestic firms, but not tracing the experience of a particular plant or firm. Many studies provide evidence that foreign owned subsidiaries are more productive than domestic firms (see Barba Navaretti and Venables 2004 for a survey). The foreign ownership premium is large in unconditional comparisons based on OLS

\footnotetext{
${ }^{15}$ Aghion, Boulanger, Cohen, 2011 argue that a decentralised allocation of funds is more effective as it allows for a clearer identification of the costs and benefits of the measures. However, there are risks that this increases the likelihood of inefficient competition, reduces the likelihood of rigorous appraisal, and increases the risk of capture by local lobbies.
} 
estimations (see for example, Davies and Lyons 1991 on the UK, and studies for other countries including Globerman et al. 1994, Doms and Jensen 1998, Blomstrom and Wolff 1994, Sjoholm 1999, Kokko, Tansini and Zejan 2001, Haddad and Harrison 1993).

Establishing a causal relationship is hard because of selection effects; superior performance of foreign affiliates may reflect cherry picking of acquisition targets rather than productivity advantages brought by foreign ownership. A few studies are able to identify the effect of change in ownership. Findings here are mixed. Conyon et al. (2002) compare data of British firms before and after a foreign acquisition. They find that these companies experience a $14 \%$ increase in labour productivity after acquisition and these gains also result in $3.4 \%$ higher wages. In contrast, Harris and Robinson (2002) find that foreign firms systematically acquire more productive British plants but there is a small decline in productivity after acquisition.

Studies that use a conditional approach, taking into account observed and unobserved heterogeneity and controlling for the simultaneity problem still find a small positive effect of foreign ownership on performance and never a negative premium (Griffith, 1999, Harris, 2002, Harris and Robinson, 2003 on the UK and Benfratello and Sembenelli, 2002 on Italy).

Productivity differences do not necessarily translate into real income gains for the host economy; the benefits might all be captured by the MNC. Researchers have therefore looked at evidence on wage differentials, and several papers find MNCs paying higher wages. We have already mentioned Conyon (2002). Girma and Gorg (2007) find that foreign acquisitions in a sample of UK firms are associated with wage increases, although the size of the effect depends on the skill of workers and the nationality of the purchasers.

Once again, it is difficult to separate selection and compositional effects from causal effects. A study that does this is Heyman, Sjöholm and Tingvall (2007) who use detailed matched employer-employee for the second half of 1990s for Sweden. They are able to control for both time invariant individual- and firm-specific effects, thus accounting for a systematic sorting of individuals across firms. Once they do so, the small foreign ownership wage premium found in less demanding specifications becomes negative and equal to -2 percent.

Taken together, the evidence broadly supports the view that MNCs are somewhat more productive and pay somewhat higher wages. When considering the methodological issues arising when trying to isolate the causal effect of changes in ownership, a note of caution is necessary. The conditional approach controls for all those other factors that come along with foreign ownership and make foreign firms different from domestic ones. These factors may in themselves be of value to the domestic economy - for example importing better management techniques, new technologies, or better market access. The bottom line is then, that foreign firms induce a favourable composition effect on average performance, both because their attributes and inputs are different from those of domestic firms, and because they use their inputs slightly more efficiently.

\section{Corporate control}

MNC activity is part of a process of increasing internationalisation of corporate control. This has some positive effects. The increased contestability of national assets imposes competitive discipline on managers and should thereby enhance efficiency. Furthermore, a larger pool of potential buyers and larger market for national assets may have positive effects on the prices at which such assets are traded. On the down-side, there may be concerns about the long-run commitment of the MNC to the host country. Adverse consequence might include instability 
of employment or reluctance to make investments the benefits of which may accrue in the far future.

Such evidence as we have on employment provides little support for the idea that MNCs are less stable employers. Barba Navaretti et al. (2003) look at the short and long run employment responses to wage and output shocks of foreign owned and domestic firms in Europe. They find that foreign owned firms adjust much faster than local firms, but the magnitude of changes is smaller. Thus, employees of a foreign owned firm are less likely to be laid off in response to a negative shock, but if it happens it happens fast. Fabbri, Haskel and Slaughter (2002) also find that MNCs have lower labour demand elasticities than domestic firms. Less positive is the evidence on plant closure. Girma and Gorg (2002) examine this issue for the UK electronics and food industry between 1980 and 1993. They find that a foreign takeover reduces the lifetime of the acquired plant in both industries under study.

A further concern is the willingness of foreign owned or controlled MNCs to undertake investments in activities that are partly local public goods. Investments in building a skilled local labour force (e.g. through apprenticeships and work with local schools and colleges), a good local work environment and supporting public facilities, payoff only if the firm has a long-term commitment to the area. There is no systematic body of evidence on this, although in section 2 we cited evidence of inwards FDI doing more training than local firms. We suspect that 'short-termism' is not a phenomenon particular to foreign investments in a country.

\section{Policy responses}

Despite these observations, acquisition of national firms does on occasion raise concerns and vocal policy stances for the preservation of national ownership. While the UK is liberal on this matter some other countries are more interventionist, with regulations on strategic assets and sovereign or mixed private/ public funds to intervene and buy national assets.

Some policies relate to assets in the areas of security and defence. For example, France has tight rules on ownership; German legislation monitors and may restrict the acquisition of more than $25 \%$ of the shares in security sensitive activities. Italy is less restrictive than Germany and France, but still has provisions restricting the acquisition of firms in the defence and energy sectors.

Going beyond security and defence, France introduced rules in 2005 forcing investors to communicate their activities whenever a transaction would result in the acquisition of all or part of a line of business, or than a third of the shares or voting rights in a French company. Foreign investors must communicate their future investment intentions whenever their share rises above $10 \%$ and $20 \%$ of shares or voting rights. While these are just obligations to inform national authorities they can become a tool of moral suasion (Alvaro and Ciccaglioni 2012). France and Italy have also set up strategic investment funds, which are private/public investment vehicles, operating at market conditions, with the aim of providing national long term financial partnership to strategic companies and to medium enterprises aiming at growing and consolidating their activities, without necessarily involving foreign partners.

Despite these measures taken by some countries, our view is that the issues of short-termism and lack of embeddedness in the local economy are not particular to MNCs or to foreign owned firms. The debate on corporate governance needs to be conducted for all firms, not particularly MNCs. 


\section{Concluding comments}

We have argued that there may be substantial gains from having footloose MNCs invest in one's region; gains arise as employment is created, wages are bid up, and also through the prospect of strengthening clusters of activity and creating knowledge and other positive spillovers. Furthermore, there is evidence that policy has been successful in attracting investment project to particular regions.

However, the case for active use of public funds needs to pass a high hurdle, needing robust evidence that there is investment creation not just investment diversion, that new investments create real income gains, and that the policy is cost effective, delivering value for money. These are hard criteria to meet, and we think that most industrial policy fails to meet them. The chances of success might be increased if three principles are followed.

First, there needs to be a rigorous framework of supra-national rules to prevent inefficient competition for projects. EU State Aids policy provides a good framework, but could go further in capping levels of subsidy that can be offered. Second, policy should operate on clearly identified market failures. The case for support to horizontal activities such as supporting backwards regions, $\mathrm{R} \& \mathrm{D}$, or to energy saving and environmental measures is more robust than that for vertical measures of support to particular sectors or firms. Third, effective procedures need to be put in place at the point where decisions are taken. Whatever the imponderables, the case should be articulated in terms of a cost-benefit analysis laying out likely impacts, including measures of displacement and deadweight loss. 


\section{References}

Aghion, P., Boulanger, J. and Cohen, E. (2011), Rethinking Industrial Policy, Bruegel Policy Brief, 20011/04.

Alvaro, S., and Ciccaglioni, P. (2012), 'I Fondi Sovrani e la Regolazione degli Investimenti nei Settori Strategici', mimeo, Consob.

Baldwin, R.E., and Venables A.J. (2013), 'Spiders and Snakes: Off-shoring and Agglomeration in The Global Economy', Journal of International Economics, forthcoming.

Balsvik, R., (2010), 'Is Labor Mobility a Channel for Spillovers from Multinationals? Evidence from Norwegian Manufacturing', Review of Economics and Statistics, forthcoming.

Barba Navaretti, G., Checchi D., and Turrini, A. (2003), 'Adjusting Labour Demand: Multinational vs. National Firms, A Cross-European Analysis', Journal of the European Economic Association, 1, 708 - 719.

Barba Navaretti, G., and Venables, A. J. (2004), Multinational Firms in the World Economy, Princeton University Press, Princeton.

Benassy-Quere, A., Coupet, M., and Mayer T. (2007), 'Institutional Determinants of Foreign Direct Investment,' The World Economy, 30, 764-782.

Bénassy-Quéré, A., Fontagné, L., Lahrèche-Revil, A. (2003), 'Tax Competition and Foreign Direct Investment', Working Papers No. 2003-17, CEPII Research Center.

Benfratello, L., and Sembenelli, A. (2002), 'Foreign Ownership and Productivity: Is the Direction of Causality so Obvious?', Centro Studi d'Agliano Working Papers No.166.

Bernard, A., Jensen, B., Redding S., and Schott, P. (2012), 'The Empirics of Firm Heterogeneity and International Trade', Annual Review of Economics, 4, 283-313.

Bérubé, C., and Mohnen, P. (2009), 'Are Firms that Receive R\&D Subsidies More Innovative?', Canadian Journal of Economics, 42(1), 206-225.

Blalock, G., and Gertler, P. J. (2008), 'Welfare Gains from Foreign Direct Investment through Technology Transfer to Local Suppliers', Journal of International Economics, 74, 402-421.

Blomström, M., and Wolff, E. (1994), 'Multinational Corporations and Productivity Convergence in Mexico', in W. Baumol, R. Nelson and E. Wolff (eds.), Convergence of Productivity: Cross-National Studies and Historical Evidence, Oxford, Oxford University Press.

Bloom, N., Griffith, R., and Van Reenen, J. (2002), 'Do R\&D Tax Credits Work? Evidence From a Panel of Countries, 1979-1997' Journal of Public Econonomics, 85, 1-31.

Branstetter, L.G., and Sakakibara, M. (2002), 'When Do Research Consortia Work Well and Why? Evidence from Japanese Panel Data', American Economic Review, 92(1), 143 159.

Bronzini, R., and Piselli, P. (2013), 'The Impact of R\&D Subsidies on Firm Innovation', Bank of Italy, mimeo.

Buigues, P. A., Sekkat, K. (2011), 'Public Subsidies to Business: An International Comparison', Journal of Industry, Competition and Trade, 11(1), 1-24.

Chung, W., Mitchell, W., and Yeung, B. (2003). 'Foreign Direct Investment and Host Country Productivity: The American Automotive Component Industry in the 1980s', Journal of International Business Studies 34, 199-218.

Conyon, M. J., Girma, S., Thompson, S. and Wright, P. (2002), 'The Productivity and Wage Effects of Foreign Acquisition in the United Kingdom', Journal of Industrial Economics 50(1), 85-102. 
Criscuolo, C., Martin, R., Overman, H.G., and Van Reenen, J. (2012), 'The Causal Effects of an Industrial Policy,' NBER Working Papers No. 17842.

Davies, S., and Lyons B. (1991), 'Characterizing Relative Performance: the Productivity Advantage of Foreign Owned Firms in the UK', Oxford Economic Papers 43, 584595.

Del Bo, C., C. Fiorio and M. Florio (2011), 'Shadow Wages for the EU Regions', Fiscal Studies 32(1)

De Mooij, R.A., and Ederveen, S. (2008), 'Corporate Tax Elasticities: a Reader's Guide to Empirical Findings', Oxford review of Economic Policy, 24(4), 680-697.

Devereux, M. P. (2008), 'Taxation of Outbound Direct Investment: Economic Principles and Tax Policy Considerations', Oxford Review of Economic Policy, 24(4), 698-719.

Devereux, M.P., Griffith, R., (2003), 'Evaluating Tax Policy for Location Decisions', International Tax and Public Finance, Springer, 10(2), 107-26, March.

Devereux, M. P., Griffith, R., and Simpson, H. (2007), 'Firm Location Decisions, Regional Grants and Agglomeration Externalities', Journal of Public Economics, 91(3-4), 413435.

Devereux, M. P., and Lockwood, B. (2006),'Taxes and the Size of the Foreign-Owned Capital Stock: Which Tax rates Matter?', paper presented at the European Tax policy Forum Conference, The Impact of Corporation Taxes Across Borders, London, April.

Devereux, M. P., Lockwood, B., and Redoano, M. (2008), 'Do Countries Compete Over Corporate Tax Rates?', Journal of Public Economics, 92(5-6),1210-1235.

Dewatripont, M., and Seabright, P. (2006), 'Wasteful Public Spending and State Aid Control', Journal of the European Economic Association, 4(2-3), 513-522.

Doms, M.E., and Jensen, J.B. (1998), 'Comparing Wages, and Productivity between Domestically and Foreign-Owned Manufacturing Establishments in the United States', in R.E. Baldwin et al. (eds), Geography and Ownership as Bases for Economic Accounting, Studies in Income and Wealth, Chicago: University of Chicago Press, 59, 235-258.

Du, L., Harrison, A., and Jefferson, G. (2011), 'Testing for Horizontal and Vertical Foreign Investment Spillovers in China, 1998-2007', Journal of Asian Economics 23(3), 234243.

European Commission,(2012) 'Industrial performance Scoreboard and member Sates' Competitiveness Performance and Policies', SWD(2012)298.

Fabbri, F., Haskel, J. E., and Slaughter, M. J. (2002), 'Globalisation and Labour Demand Elasticities in Britain', paper presented at the 'Adjusting to Globalisation' conference, University of Nottingham, June.

Falk, M. (2004), 'What Drives Business R\&D Intensity Across OECD Countries?' WIFO Working Papers, No. 236.

Filer, R., Schneider, O. , and Svejnar, J. (1995), 'Wage and Non-wage Labour Cost in the Czech Republic: The Impact of Fringe Benefits', CERGE-EI Working Paper No.77, Prague.

Girma, S., and Görg, H. (2002), 'Multinationals' Productivity Advantage: Scale or Technology?', mimeo.

Girma, S., and Görg, H. (2007), 'Multinationals' Productivity Advantage: Scale or Technology?', Economic Inquiry, 45(2), 350-362.

Globerman, S., Ries J., Vertinski I. (1994), 'Economic Performance of Foreign Affiliates in Canada', Canadian Journal of Economics, 27, 143-156.

Görg, H., and Greenaway, D. (2004), 'Much Ado about Nothing? Do Domestic Firms Really Benefit from Foreign Direct Investment?’,World Bank Research Observer, 19(2), 171-197. 
Görg, H., and Strobl, E. (2001),'Multinational Companies and Productivity Spillovers: A Meta-analysis', Economic Journal, 111, 723-739.

Greenstone, M., Hornbeck, R., and Moretti, E. (2010), 'Identifying Agglomeration Spillovers: Evidence from Winners and Losers of Large Plant Openings', Journal of Political Economy, 118(3), 536-598.

Griffith, R. (1999), 'Using the ARD Establishment Level Data to Look at Foreign Ownership and Productivity in the United Kingdom', Economic Journal, 109(456), 416-42.

Griffith, R., Redding, S., and Simpson, H. (2004), 'Foreign Ownership and Productivity: New Evidence From the Service Sector and the R\&D Lab', Oxford Review of Economic Policy 20(3), 440-456.

Guellec, D., and Pottelsberghe de la Potterie, B., (2003), 'The Impact of Public R\&D Expenditure on Business R\&D', Economics of Innovation and New Technology, 12(3), 225-244.

Haddad, M., and Harrison, A. (1993), 'Are there Positive Spillovers from Direct Foreign Investment? Evidence from Panel Data for Morocco', Journal of Development Economics, 42, 51-74.

Hansson, Å., and Olofsdotter, K. (2010), 'Tax differences and foreign direct investment in the EU27',Working Papers No.2010:3, Lund University, Department of Economics.

Harris, R., and Robinson, C. (2002), 'The Effect of Foreign Acquisitions on Total Factor Productivity: Plant-Level Evidence from U.K. Manufacturing, 1987-1992', The Review of Economics and Statistics, 84(3), 562-568.

Harris, R., and Robinson, C. (2003), 'Foreign Ownership and Productivity in the United Kingdom Estimates for U.K. Manufacturing Using the ARD', Review of Industrial Organization, 22(3).

Harrison, A., and Rodríguez-Clare, A. (2010), 'Trade, Foreign Investment, and Industrial Policy for Developing Countries'. In D. Rodrik and M. Rosenzweig (ed), Handbook of Development Economics, 5, 4039-4214, The Netherlands: North-Holland.

Haskel, J. E., Pereira, S.C., and Slaughter, M. J. (2007), 'Does Inward Foreign Direct Investment Boost the Productivity of Domestic Firms?' Review of Economics and Statistics, 89(2).

Heyman, F., Sjöholm, F., Tingvall, P. (2007), 'Multinationals, Cross-border Acquisitions and Wage Dispersion', Canadian Journal of Economics, 44(2), 627-650.

Hines, J. R. (1999), 'Lessons from Behavioral Responses to International Taxation', National Tax Journal, 52, 305-322.

Javorcik, B. S. (2004),' Does Foreign Direct Investment Increase the Productivity of Domestic Firms? In Search of Spillovers Through Backward Linkages', American Economic Review, 94(3), 605-627.

Javorcik, B. S., Keller, W., and Tybout, J. (2008), 'Openness and Industrial Response in a Wal-Mart World: A Case Study of Mexican Soaps, Detergents and Surfactant Producers', The World Economy, 31(12).

Javorcik, B. S., and Spatareanu, M. (2008), 'To Share or Not to Share: Does Local Participation Matter for Spillovers from FDI?', Journal of Development Economics, 85(1-2), 194-217.

Kokko A, Gustavsson, P. (2004), 'Regional integration, FDI, and Regional Development', EIB Papers, 9(1), 111-35.

Kokko, A., Tansini, R., and Zejan, M. (2001), 'Trade Regimes and Spillover Effects of FDI: Evidence from Uruguay', Weltwirtschaftliches Archiv, 137(1), 124-149.

Konrad, K.A., and Kovenock, D. (2009), 'Competition for FDI with Vintage Investment and Agglomeration Advantage', Journal of international Economics, 79, 230-237. 
Liu, Z. (2008), 'Foreign Direct Investment and Technology Spillovers: Theory and Evidence, Journal of Development Economics, 85(1-2), 176-193.

Mayer, T. (2004), 'Where Do Foreign Firms Locate in France and Why?' EIB Papers, 9(2).

Moretti, E. (2010), 'Local Multipliers', American Economic Review: Papers and Proceedings, 100(1-7).

Moretti, E., and Thulin, P. (2012), 'Local Multipliers and Human Capital in the US and Sweden', Working Peper Series No. 914, Research Institute of Industrial Economics.

Nathan. M. and H.G. Overman (2013), 'Agglomeration, clusters and industrial policy' Oxford Review of Economic Policy, this issue.

Parisi, M., and Sembenelli, A., (2003), 'Is Private R \& D Spending Sensitive to Its Price? Empirical Evidence on Panel Data for Italy', Empirica, Springer, 30(4), 357-377, December.

Sjöholm, F. (1999), 'Productivity Growth in Indonesia: The Role of regional Characteristics and Direct Foreign Investment', Economic Development and Cultural Change, 47(3), 559-584.

Smeets, R. (2008), 'Collecting the Pieces of the FDI Knowledge Spillovers Puzzle', World Bank Research Observer, 23(2), 107-138.

World Bank, 'Doing Business Reports', several years.

World Economic Forum, 'Global Competitiveness Indicators' several years.

Yeaple, S.R. (2009), 'Firm Heterogeneity and the Structure of US Multinational Activity; an Empirical Analysis, Journal of International Economics, 78, 206-15. 